PREPARED FOR THE U.S. DEPARTMENT OF ENERGY, UNDER CONTRACT DE-AC02-76CH03073

PPPL-3553

PPPL-3553

UC-70

Effect of Boronization on Ohmic Plasmas in NSTX

by

C.H. Skinner, H. Kugel, R. Maingi, W.R. Wampler, W. Blanchard, M. Bell, R. Bell, B. LeBlanc, D. Gates, S. Kaye, P. LaMarche, J. Menard, D. Mueller, H.K. Na, N. Nishino, S. Paul, S. Sabbagh, and V. Soukhanovskii

Revised April 6, 2001

NM|

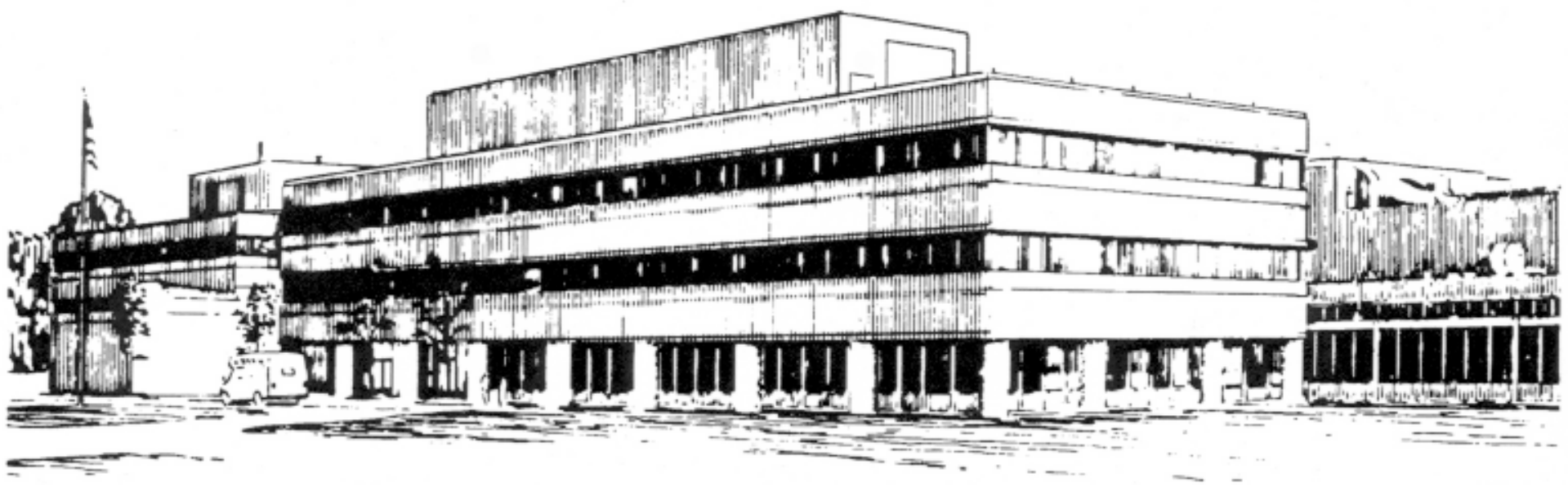

PRINCETON PLASMA PHYSICS LABORATORY PRINCETON UNIVERSITY, PRINCETON, NEW JERSEY 


\section{PPPL Reports Disclaimer}

This report was prepared as an account of work sponsored by an agency of the United States Government. Neither the United States Government nor any agency thereof, nor any of their employees, makes any warranty, express or implied, or assumes any legal liability or responsibility for the accuracy, completeness, or usefulness of any information, apparatus, product, or process disclosed, or represents that its use would not infringe privately owned rights. Reference herein to any specific commercial product, process, or service by trade name, trademark, manufacturer, or otherwise, does not necessarily constitute or imply its endorsement, recommendation, or favoring by the United States Government or any agency thereof. The views and opinions of authors expressed herein do not necessarily state or reflect those of the United States Government or any agency thereof.

\section{Availability}

This report is posted on the U.S. Department of Energy's Princeton Plasma Physics Laboratory Publications and Reports web site in Calendar Year 2001. The home page for PPPL Reports and Publications is: http://www.pppl.gov/pub_report/

DOE and DOE Contractors can obtain copies of this report from:

U.S. Department of Energy

Office of Scientific and Technical Information

DOE Technical Information Services (DTIS)

P.O. Box 62

Oak Ridge, TN 37831

Telephone: (865) 576-8401

Fax: (865) 576-5728

Email: reports@adonis.osti.gov

This report is available to the general public from:

National Technical Information Service

U.S. Department of Commerce

5285 Port Royal Road

Springfield, VA 22161

Telephone: 1-800-553-6847 or

(703) 605-6000

Fax: (703) 321-8547

Internet: http://www.ntis.gov/ordering.htm 


\title{
Effect of Boronization on Ohmic Plasmas in NSTX
}

\author{
C. H. Skinner, H. Kugel, R. Maingi, W. R. Wampler ${ }^{\text {, }}$ W. Blanchard, M. Bell, R. Bell,
} B. LeBlanc, D. Gates, S. Kaye, P. LaMarche, J. Menard, D. Mueller, H.K. Na ${ }^{\mathrm{c}}$, N. Nishino ${ }^{\mathrm{d}}$, S. Paul, S. Sabbagh, V. Soukhanovskii

\author{
Princeton Plasma Physics Laboratory, Princeton, New Jersey, 08543 USA \\ ${ }^{b}$ Sandia National Laboratories, Albuquerque NM 87175 USA \\ ${ }^{c}$ Korea Basic Science Institute, Daejeon, South Korea \\ ${ }^{\mathrm{d}}$ Hiroshima University, Hiroshima, Japan
}

\begin{abstract}
:
Boronization of the National Spherical Torus Experiment (NSTX) has enabled access to higher density, higher confinement plasmas. A glow discharge with 4 mTorr helium and 10\% deuterated trimethyl boron deposited $1.7 \mathrm{~g}$ of boron on the plasma facing surfaces. Ion beam analysis of witness coupons showed a $\mathrm{B}+\mathrm{C}$ areal density of $10^{18}(\mathrm{~B}+\mathrm{C}) \mathrm{cm}^{-2}$ corresponding to a film thickness of $100 \mathrm{~nm}$. Subsequent ohmic discharges showed oxygen emission lines reduced by $\mathrm{x} 15$, carbon emission reduced by two and copper reduced to undetectable levels. After boronization, the plasma current flattop time increased by $70 \%$ enabling access to higher density, higher confinement plasmas.
\end{abstract}

Keywords: wall conditioning, boronization, trimethylboron.

\section{Introduction}

Wall conditioning has proved to be key to achieving high performance in fusion devices[1]. The reservoir of particles in the wall surface typically exceeds that in the plasma by orders of magnitude and hydrogenic and impurity influx needs to be controlled to permit density control and minimize radiative losses. Wall conditioning techniques include baking and discharge cleaning to deplete the surface of trapped hydrogen, and coatings to modify the properties of plasma facing surfaces. One of the most successful wall coating techniques is the plasma assisted chemical vapor deposition of boron on plasma facing surfaces. This was pioneered at TEXTOR[2] using a radio frequency assisted glow discharge of $80 \% \mathrm{He}, 10 \% \mathrm{CH}_{4}$ 
and $10 \%$ diborane $\left(\mathrm{B}_{2} \mathrm{H}_{6}\right)$ that deposited a $40 \mathrm{~nm}$ thick amorphous boron/carbon film (a-B/C:D). This film gettered oxygen and resisted chemical erosion and led to tokamak discharges with significantly reduced oxygen and carbon impurities. Boronization using different boron compounds has led to a very high confinement mode (VH-mode) in DIII-D (diborane)[3] and improved access to the H-mode regime in C-mod (diborane) [4] and MAST (trimethyl boron)[5]. Diborane, in particular, needs special handling due to its explosive and toxic properties, but boronization using the less hazardous compound, trimethyl boron (TMB), $\mathrm{B}\left(\mathrm{CH}_{3}\right)_{3}$ was found to have similar effects $[5,6,7]$. A comparison of TMB and decaborane on Phaedrus-T showed three times lower core oxygen for TMB and about $40 \%$ higher edge carbon (CII) [8]. Boronization in tokamaks is reviewed in ref. [9]. A comprehensive review of plasma materials issues in next-step devices is presented in ref. [10].

The National Spherical Torus Experiment (NSTX) [11] began operations in February 1999. The research program is aimed at extending the understanding toroidal confinement physics at low aspect ratio in collisionless, high- $\beta$ regimes and to demonstrate non-inductive current generation and sustainment[12,13]. A range of plasma shapes and configurations have been produced with plasma currents up to $1 \mathrm{MA}$, with stored energies up to $55 \mathrm{~kJ}$ in ohmic plasmas and over $90 \mathrm{~kJ}$ in initial experiments with neutral beam heating. The injection of $2 \mathrm{MW}$ of High Harmonic Fast Wave power (HHFW) has produced electron temperatures up to 1.15 $\mathrm{keV}[14]$. The magnetic field line geometry differs from conventional tokamaks in that the outboard edge field line pitch of $45^{\circ}$ results in a shorter outer connection length from the midplane to the inner wall. The strong variation in the magnitude of the magnetic field is expected to result in a large mirror trapped ion flux in the SOL. The vacuum vessel of 304 stainless steel has a volume of $30 \mathrm{~m}^{3}$ and area $41 \mathrm{~m}^{2}$. It has internal copper passive stabilizing plates and divertor plates both covered with graphite tiles. The $0.2 \mathrm{~m}$ radius center column is clad with alternating vertical columns of graphite (Union Carbide, Type ATJ) tiles between columns of 2-D Carbon Fiber Composite (CFC) (Allied Signal, Type 865-19-4) tiles. As expected discharge reproducibility, density control and performance were strongly affected by wall conditions and variety of wall conditioning techniques have been employed[15]. The center column has been baked to $309 \mathrm{C}$ by resistive heating. The divertor plates, passive plates and vessel wall have been baked to $150 \mathrm{C}$. Deuterium glow discharge cleaning (D-GDC) was found 
to be effective in removing impurities from the wall, and helium glow discharge cleaning (HeGDC) for removing residual D. The short connection length on the outboard side and high mirror ratio are unique features of spherical tori and it is interesting to compare the response of NSTX to boronization to that of other machines.

\section{Boronization}

The NSTX glow discharge (GDC) system has 304-SS anodes at vessel bays K and G (Fig. 1). Deuterated trimethyl boron was used as hydrogen is incompatible with HHFW due to parasitic resonances. The midplane Bay L gas feed system was used to supply TMB and it was exhausted with the existing torus pumping system. To minimize pyrophoric risk, nitrogen was added to reduce the oxygen partial pressure in the exhaust line. Using one turbomolecular pump of the two pump system and with the vessel at room temperature, a standard He-GDC is initiated using a filiament preionization system with 4 mtorr gas pressure, $450 \mathrm{~V}, 1.5$ A per electrode. After approximately 10 minutes of He gas feed, a mixture of 90\% He and 10\% TMB was added to the pure $\mathrm{He}$ in the gas feed. The process continued for about $160 \mathrm{~m}$ until the $10 \mathrm{~g}$ TMB cylinder was almost exhausted and resulted in about $100 \mathrm{~nm}$ thick a-B/C:D film. This was followed by 2 hours of He-GDC to remove co-deposited deuterium from the near surface region of the film and reduce D influx during subsequent high power plasmas. Residual gas mass analysis after boronization indicated a significant reduction in mass $18\left(\mathrm{H}_{2} \mathrm{O}\right)$, mass $28(\mathrm{CO})$, and hydrocarbons.

A polished silicon $25 \mathrm{~mm}$ square sample coupon was located on the vessel wall (major radius, $\mathrm{R}=169 \mathrm{~cm}$ ) at Bay $\mathrm{E}$ and exposed to the first boronization. After boronization, the coupon was retrieved and the deposited film characteristics measured by ion beam analysis. The boron areal density was measured via the ${ }^{11} \mathrm{~B}\left({ }^{1} \mathrm{H},{ }^{4} \mathrm{He}\right){ }^{8} \mathrm{Be}$ nuclear reaction with a $650 \mathrm{eV}$ proton beam, deuterium by the ${ }^{2} \mathrm{D}\left({ }^{3} \mathrm{He}, \mathrm{p}\right){ }^{4} \mathrm{He}$ reaction with a $700 \mathrm{keV}{ }^{3} \mathrm{He}$ beam and carbon was measured by Rutherford backscattering with a $1500 \mathrm{keV}$ proton beam. The ion beam probes the entire thickness of the film. Four analysis sites were spaced $5 \mathrm{~mm}$ apart on a line through the center of the coupon and the results are summarized in Table 1 . The $\mathrm{B}+\mathrm{C}$ areal density was $10^{18}$ $(\mathrm{B}+\mathrm{C}) \mathrm{cm}^{-2}$ corresponding to a film thickness of $100 \mathrm{~nm}$, similar to the $96 \mathrm{~nm}$ calculated thickness of $10 \mathrm{~g}$ of TMB deposited uniformly over the $\approx 41 \mathrm{~m}^{2}$ surface area of the vessel. The $\mathrm{B} / \mathrm{C}$ ratio of $1 / 3$ is consistent with the stoichiometric ratio in TMB (as in TEXTOR (0.38)[2], and 
in COMPASS ( 0.46 on stainless coupons)[7]) while the $\mathrm{D} /(\mathrm{B}+\mathrm{C})$ ratio was $2 / 3$. The site to site variations are believed to be due to variations in local electric field geometry and possibly redeposition from nearby surfaces. A second coupon was located at $\mathrm{R}=217 \mathrm{~cm}$ at Bay $\mathrm{E}$, beyond the vessel wall and was $477 \mathrm{~mm}$ behind a $25 \mathrm{~mm}$ aperture. This coupon showed no significant boron (detection limit $\approx 10^{14} \mathrm{~cm}^{-2}$ ).

\section{Plasma behavior}

The emission from the plasma was monitored with a $0.5 \mathrm{~m}$ Czerny Turner spectrometer operating in the range $200-700 \mathrm{~nm}$. The instrument was equipped with a reticon detector and the grating was set to monitor emission lines from different elements immediately before and after the boronization. The results are shown in Fig. 2. Frame (a) shows copper emission lines reduced to below the detection limit and oxygen emission reduced by a factor of 15 after boronization. The spectra were integrated over $0.12-0.16 \mathrm{~s}$ in discharges with similar electron density $\left(\mathrm{n}_{\mathrm{e}} \mathrm{L}=2.1 \times 10^{15} \mathrm{~cm}^{-2}\right.$ pre- and $1.8 \times 10^{15} \mathrm{~cm}^{-2}$ post-boronization). The second frame, (b), shows C II emission in the neighborhood of the (saturated) D-alpha line. The carbon emission is reduced by a factor of two. The second order copper impurity line at $3274 \AA$ disappeared after boronization. The line electron density was $1.9 \times 10^{15}$ and $2.0 \times 10^{15} \mathrm{~cm}^{-2}$ pre- and post boronization respectively. Boron emission lines e.g. at $3451 \AA$ were prominent after boronization. Oxygen levels after boronization remained low, unless there was a change in type of plasma operations (neutral beam injection, $\mathrm{CHI}[16]$, minor vent). Boronization has been repeated 5 times between intervals of 2-3 weeks.

The radiated power profile is measured from a tangential bolometer array located at the midplane. The multi-element detector is a 16-channel XUV diode array[17] and the volumeintegrated power $\mathrm{P}_{\mathrm{rad}}$ is determined using an equilibrium calculated from magnetic measurements, with the assumption that the radiated power density is constant along a flux surface. Before boronization $\mathrm{P}_{\mathrm{rad}}$ was typically $\leq 40 \%$ of the ohmic heating power and was reduced by a factor of two following boronization (Fig. 3). The reduction in impurity influx and radiated power mirrored the experience on other machines, and boronization was particularly useful in NSTX in suppressing copper impurities. 
In a pair of comparison discharges, visible bremsstrahlung emission in a $10 \AA$ region at $5230 \AA ̊$ decreased by a factor of 2 after boronization. For the post-boronization discharge the line density was somewhat higher so the change corresponded to a factor of 3 decrease in Z-effective $\left(\mathrm{Z}_{\mathrm{eff}}\right)$. Emission in this spectral region was also monitored by a fiberoptically coupled telescope viewing across the vessel at the midplane into the pump duct. The system was absolute intensity calibrated and checked against high density He discharges. $Z_{\text {eff }}$ was calculated[18] from the intensity and the electron density and temperature as measured by Thomson scattering and was in the range $\mathrm{Z}_{\text {eff }} \approx 2$ immediately following the first boronization.

Significant improvements in plasma performance were apparent after boronization in NSTX $[12,19,20]$ as on other machines[9]. Figure 4(a) shows that the duration of the plasma current flat top increased by about $70 \%$. This increase in flattop duration is particularly valuable in spherical tori because of limitations on the OH flux capabilities of the centerstack. Figure 4(b) shows that while the loop voltage temporal behavior was generally comparable pre- and post boronization, the loop voltage at time of highest stored energy (Fig. 4d) in the discharges was reduced by 30\%. Fig. 4(c) shows that the volt-second consumption was indeed lower in the post boronization discharge. The combination of constant peak stored energy and the lower loop voltage lead to a $30 \%$ higher energy confinement time in the post boronization discharge. The origin of the lower loop voltage is probably reduced carbon, oxygen, and copper impurity levels post-boronization, which lead to a lower radiated power (Fig. 3 and 4(e)) and a reduced plasma resistivity.

A by-product of the longer flat top duration was access to higher densities[12]. The deuterium density limit increased from approximately $60 \%$ of the Greenwald limit density to about $75 \%-80 \%$ after boronization, and the helium density limit increased from $75 \%$ to $100 \%$ of the Greenwald limit. The confinement time increased with increasing density up to $45 \mathrm{~ms}$ at $4 \mathrm{x}$ $10^{19} \mathrm{~m}^{-3}$ corresponding to $0.8 \mathrm{n}_{\text {eGW }}$ but dropped to about $20 \mathrm{~ms}$ at the highest densities $\left(5.5 \times 10^{19}\right.$ $\mathrm{m}^{-3}, 1.2 \mathrm{n}_{\mathrm{eGW}}$ ). At the lower density range of NSTX, the confinement time was similar in pre- and post-boronized plasmas. However the density at which confinement 'rolled over' was higher post-boronization, for both deuterium and helium discharges[12]. It is notable that access to $\mathrm{H}-$ mode plasmas was enabled only after the third boronization, and H-mode plasmas generated after the $4^{\text {th }}$ boronization were extended from $8 \mathrm{~ms}$ to $65 \mathrm{~ms}$. This suggests that subsequent 
boronizations continue to incrementally improve wall conditions [21]. An improvement was also observed on $\mathrm{C}$-mod after boronization where the reduction in radiated power led to a lower H-mode power threshold[4]. A quantitative understanding of complex link between the condition of the wall, the plasma edge and confinement remains obscure and the details hidden by the lack of real-time wall diagnostics[22].

In summary, boronization on NSTX was successful in increasing the current flattop time by $70 \%$, reducing radiated power by a factor of two, reducing Z-effective by a factor of three, reducing oxygen impurities by a factor of $\mathrm{x} 15$ and copper impurities to below the detection threshold. These changed enabled access to higher density, higher confinement plasmas, including $\mathrm{H}$-mode conditions.

Acknowledgements: We thank Dr. S. Fielding of the Culham Science Centre, MAST Team for helpful technical discussions that contributed significantly to the implementation of this technique. We acknowledge the valuable technical contributions of W. Blanchard, P. LaMarche, R. Gernhardt, T. Provost, J. Winston, T. Czeizinger, J. Gething, and M. DiMattia and the whole NSTX team. This work is supported by US Dept. of Energy Contract Nos. DE-AC0276CH03073, DE-AC04-94AL85000, DE-AC05-00OR22725, W-7405-ENG-36, W-7405-ENG48, DE-AC03-99ER54463, DE-FG02-99ER54523 and Grant no. DE-FG02-99ER54524. 
Table 1. The boron, carbon, and deuterium areal density after boronization.

\begin{tabular}{cccccc}
\hline Analysis site & $\mathrm{B} 10^{18} / \mathrm{cm}^{2}$ & $\mathrm{C} 10^{18} / \mathrm{cm}^{2}$ & $\mathrm{D} 10^{18} / \mathrm{cm}^{2}$ & $\mathrm{~B} / \mathrm{C}$ ratio & $\mathrm{D} /(\mathrm{B}+\mathrm{C})$ ratio \\
\hline \hline 1 & 0.268 & 0.703 & 0.600 & 0.38 & 0.62 \\
2 & 0.219 & 0.675 & 0.582 & 0.32 & 0.65 \\
3 & 0.238 & 0.697 & 0.592 & 0.34 & 0.63 \\
4 & 0.315 & 0.744 & 0.637 & 0.42 & 0.60 \\
\hline
\end{tabular}




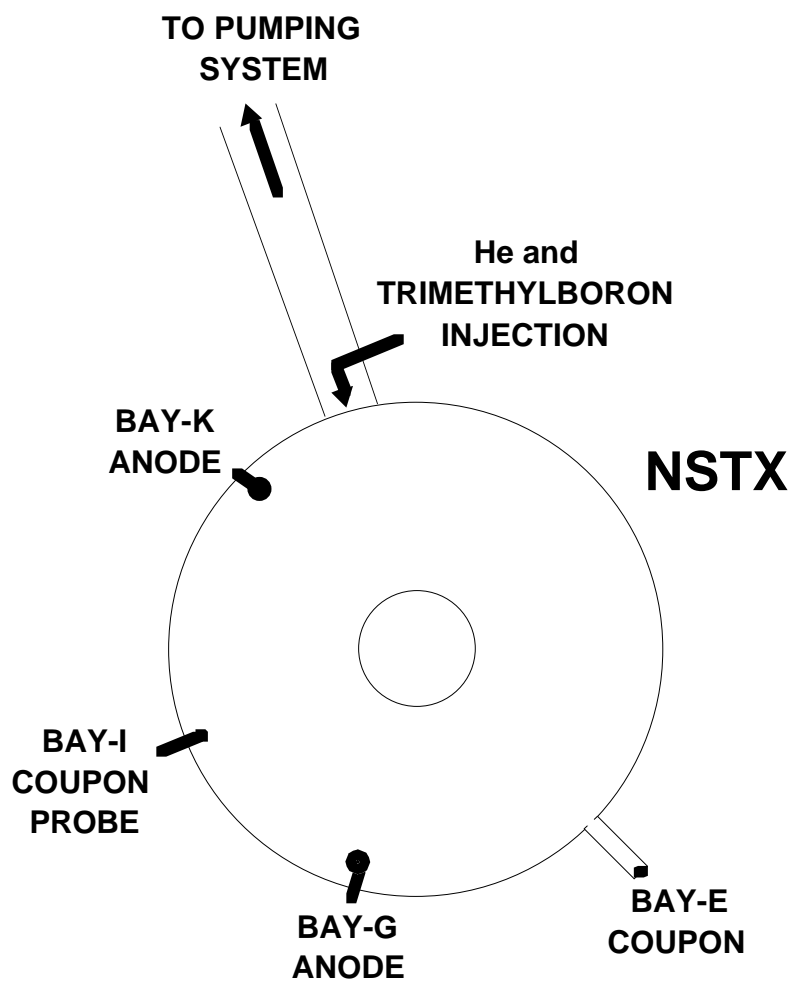

Figure 1 Plan view showing the experimental configuration of NSTX. 

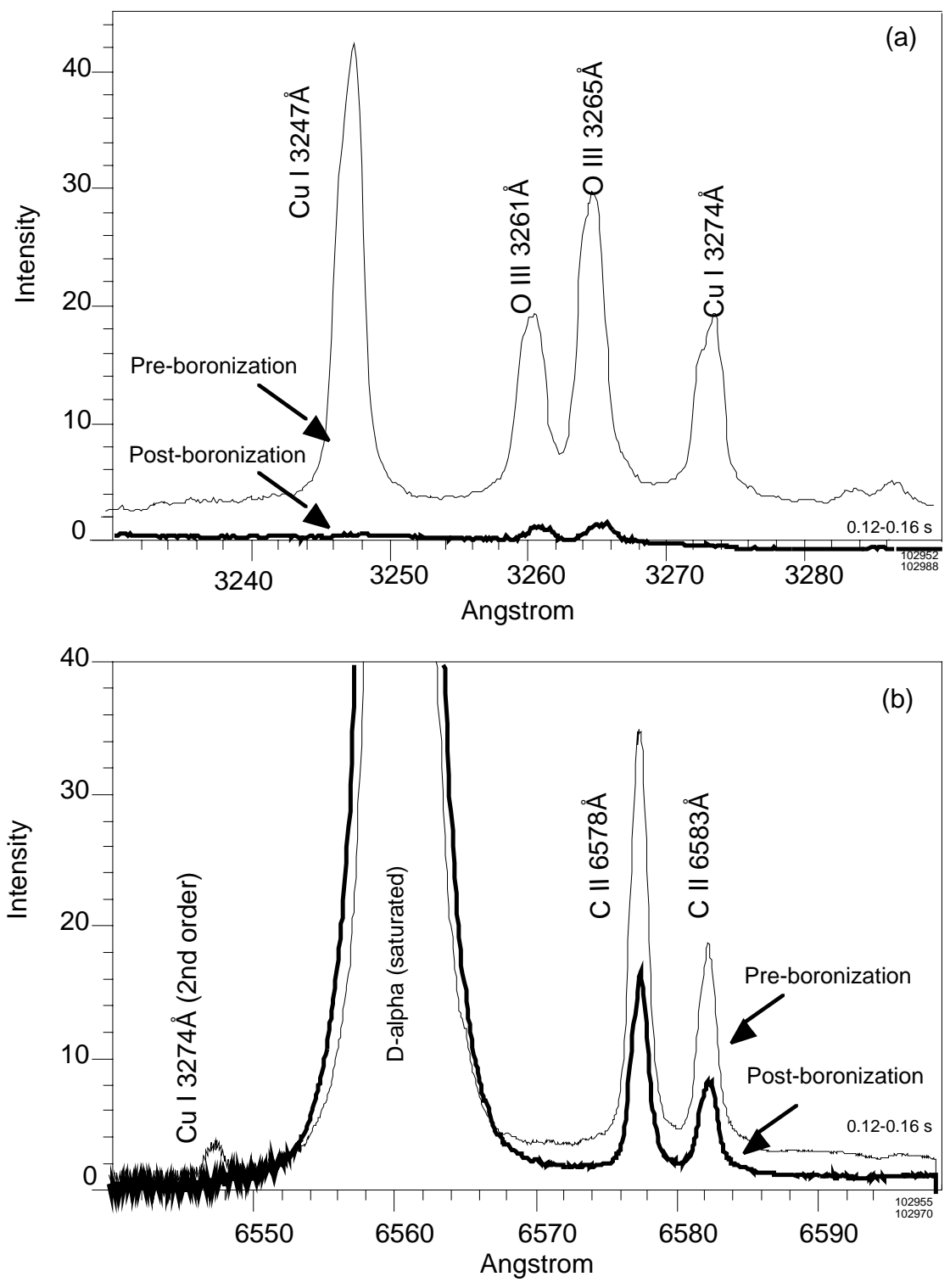

Figure 2 Comparison of impurity emission before and after boronization. 


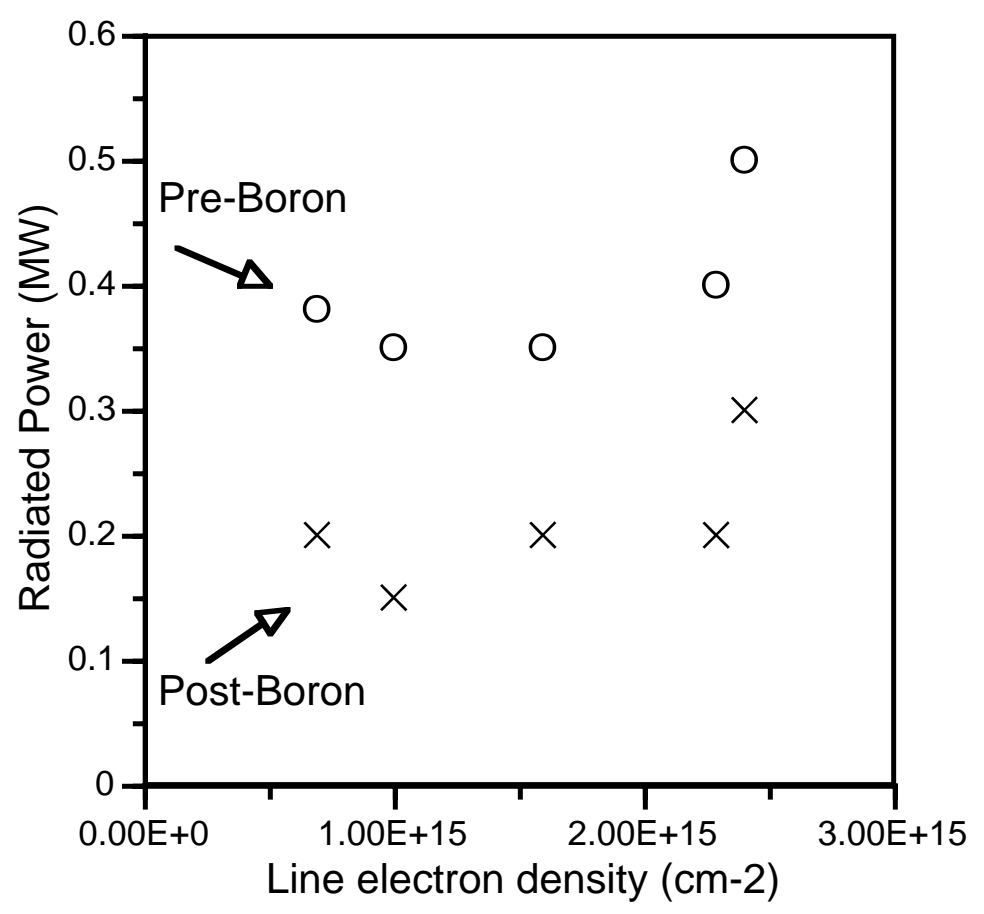

Figure 3 Change in radiated power on boronization. 


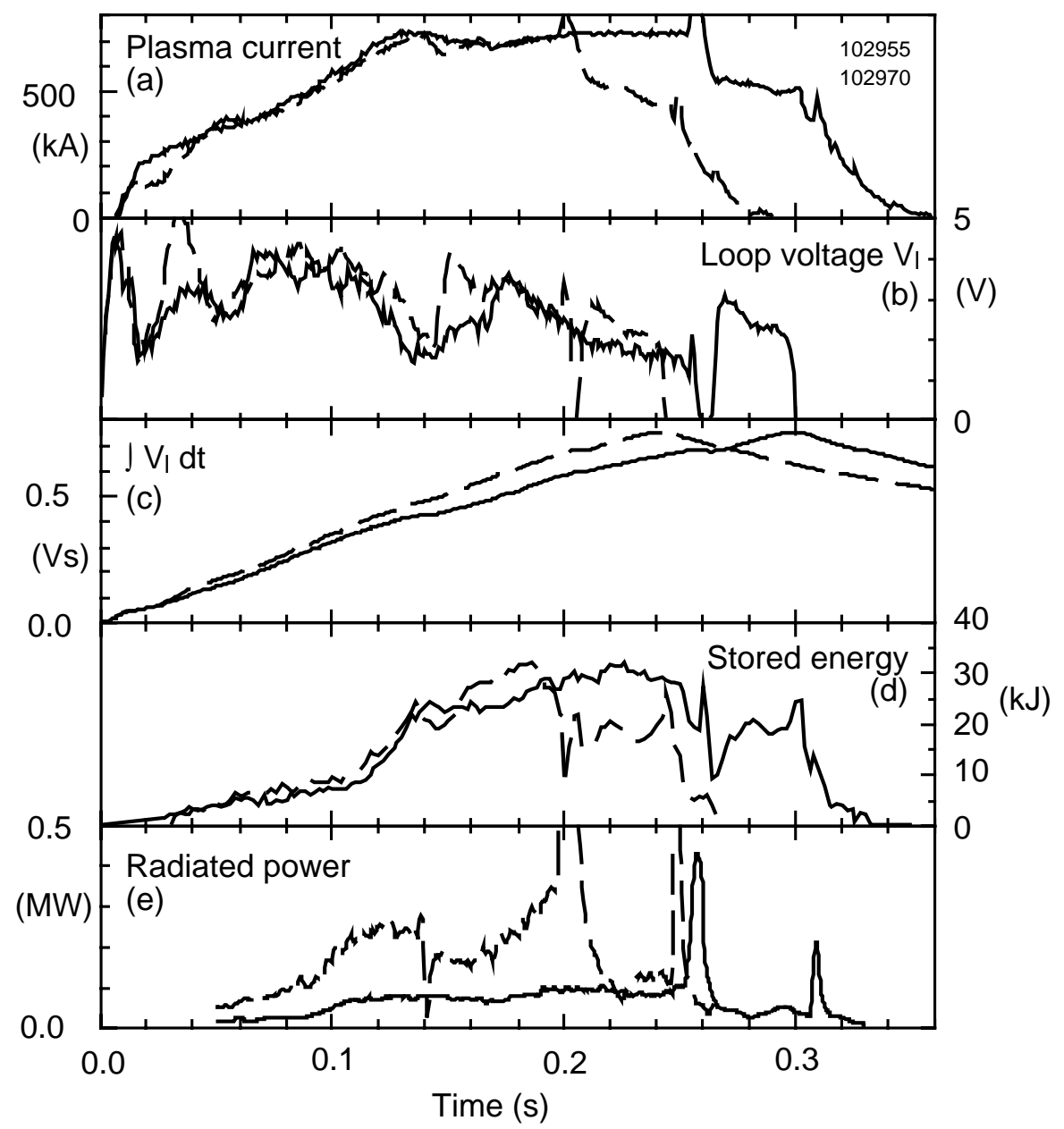

Fig. 4 Comparison of plasma parameters before and after boronization. The dashed trace is pre boronization. 


\section{References}

[1] Winter, J., Plasma Phys. Control. Fusion 38 (1966) 1503.

[2] Winter, J., Esser, H G. Könen et al., J. Nucl. Mater., 162-164 (1989) 713.

[3] Jackson, G.L., et al., Phys. Rev. Lett. 67 (1991) 3098.

[4] Greenwald, M., et al., Nucl. Fusion 37 (1997) 793.

[5] Sykes A. et al, 'First Results from MAST', IAEA meeting Sorrento Oct. 99, IAEA-CN77/OV4/1, submitted to Nuclear Fusion.

[6] Winter, J., et al., J. Nucl. Mater., 176\&177 (1990) 486.

[7] Esser, H.G. et al., J. Nucl. Mater. 186 (1992) 217.

[8] Doczy M., et al. Bull. Am. Phys. Soc. 39 (1994) 1631.

[9] Buzhinskij O. I., and Semenets Y.M., Fusion Technology, 32 (1997) 1.

[10] Federici, G., et al., "Plasma-material Interactions in Current Tokamaks and their Implications for Next-step Fusion Reactors “ Joint report by the Princeton Plasma Physics Laboratory and the Max-Planck-Institut fuer Plasmaphysik. PPPL-3531/IPP9/128 January 2001 submitted to Nuclear Fusion.

[11] Neumeyer C et al., 'Engineering design of the National Spherical Torus Experiment' Fusion Eng. \& Des. 2000 in press.

[12] Kaye S.M. et al., Physics of Plasmas, 2001 in press.

[13] Ono, $\mathrm{M}$ et al., 'Overview of the initial NSTX results' Proceedings of the 18th International Atomic Energy Agency Conference on Plasma Physics and Controlled Nuclear Fusion Research, Sorrento, Oct. 2000, IAEA-CN-77/OV4-2.

[14] Wilson R., personal communication

[15] Kugel H.K., et al., 'Overview of Impurity Control and Wall Conditioning in NSTX' Proceedings of the 14th International Conference on Plasma Surface Interactions, Rosenheim, Germany, May 22-26,2000, J. Nucl. Mater. (2001) in press.

[16] Raman R., et al., 'Non inductive current generation in NSTX using Coaxial Helicity Injection' $18^{\text {th }}$ IAEA Fusion Energy Conference, Sorrento, Italy, 4-10 Oct. 2000 IAEA$\mathrm{CN}-77 / \mathrm{EX} 8 / 5$

[17] R. L. Boivin, J. A. Goetz, E. S. Marmar, J. E. Rice, and J. L. Terry, Rev. Sci. Instrum., 70 (1999) 260. 
[18 ] Kadota K., Otsuka, M., and Fujita J., Nucl. Fus. 20 (1980) 209.

[19] Ono M., et al., 'Overview of the Initial NSTX results' $18^{\text {th }}$ IAEA Fusion Energy Conference, Sorrento, Italy, 4-10 Oct. 2000 IAEA-CN-77/OV4/2.

[20] Sabbagh, S.A., et al., 'Equilibrium Properties of Spherical Torus Plasmas in NSTX' $18^{\text {th }}$ IAEA Fusion Energy Conference, Sorrento, Italy, 4-10 Oct. 2000 IAEA-CN-77/EX 3/6

[21] Maingi, R. et. al., "Observations of the First H-mode Transitions in NSTX", submitted to Phys. Rev. Lett., 4/2001.

[22] Counsell G. F., et al., J. Nucl. Mater. in press (2001). 


\section{External Distribution}

Plasma Research Laboratory, Australian National University, Australia

Professor I.R. J ones, Flinders University, Australia

Professor J oão Canalle, Instituto de Fisica DEQ/IF - UERJ , Brazil

Mr. Gerson O. Ludwig, Instituto Nacional de Pesquisas, Brazil

Dr. P.H. Sakanaka, Instituto Fisica, Brazil

The Librarian, Culham Laboratory, England

Library, R61, Rutherford Appleton Laboratory, England

Mrs. S.A. Hutchinson, JET Library, England

Professor M.N. Bussac, Ecole Polytechnique, France

Librarian, Max-Planck-Institut für Plasmaphysik, Germany

J olan Moldvai, Reports Library, MTA KFKI-ATKI, Hungary

Dr. P. Kaw, Institute for Plasma Research, India

Ms. P.J . Pathak, Librarian, Insitute for Plasma Research, India

Ms. Clelia De Palo, Associazione EURATOM-ENEA, I taly

Dr. G. Grosso, Instituto di Fisica del Plasma, Italy

Librarian, Naka Fusion Research Establishment, J AERI, J apan

Library, Plasma Physics Laboratory, Kyoto University, J apan

Research Information Center, National Institute for Fusion Science, J apan

Dr. O. Mitarai, Kyushu Tokai University, J apan

Library, Academia Sinica, Institute of Plasma Physics, People's Republic of China

Shih-Tung Tsai, Institute of Physics, Chinese Academy of Sciences, People's Republic of China

Dr. S. Mirnov, TRINITI, Troitsk, Russian Federation, Russia

Dr. V.S. Strelkov, Kurchatov Institute, Russian Federation, Russia

Professor Peter Lukac, Katedra Fyziky Plazmy MFF UK, Mlynska dolina F-2, Komenskeho Univerzita, SK-842 15 Bratislava, Slovakia

Dr. G.S. Lee, Korea Basic Science Institute, South Korea

Mr. Dennis Bruggink, Fusion Library, University of Wisconsin, USA

Institute for Plasma Research, University of Maryland, USA

Librarian, Fusion Energy Division, Oak Ridge National Laboratory, USA

Librarian, Institute of Fusion Studies, University of Texas, USA

Librarian, Magnetic Fusion Program, Lawrence Livermore National Laboratory, USA

Library, General Atomics, USA

Plasma Physics Group, Fusion Energy Research Program, University of California at San Diego, USA

Plasma Physics Library, Columbia University, USA

Alkesh Punjabi, Center for Fusion Research and Training, Hampton University, USA

Dr. W.M. Stacey, Fusion Research Center, Georgia Institute of Technology, USA

Dr. J ohn Willis, U.S. Department of Energy, Office of Fusion Energy Sciences, USA

Mr. Paul H. Wright, Indianapolis, Indiana, USA 
The Princeton Plasma Physics Laboratory is operated by Princeton University under contract with the U.S. Department of Energy.

\author{
Information Services \\ Princeton Plasma Physics Laboratory \\ P.O. Box 451 \\ Princeton, NJ 08543
}

Phone: 609-243-2750

Fax: 609-243-2751

e-mail: pppl_info@pppl.gov

Internet Address: http://www.pppl.gov 